

Camilla Brørup Dyssegaard \& Michael Søgaard Larsen

\section{Kvalitet på specialskoler: \\ En kortfattet systematisk forskningskortlægning}

Dansk Clearinghouse for Uddannelsesforskning Institut for Uddannelse og Pædagogik (DPU)

Aarhus Universitet, 2014 
Dansk Clearinghouse for Uddannelsesforskning

er en enhed ved Aarhus Universitet

Titel Kvalitet på specialskoler:

En kortfattet systematisk forskningskortlægning

Forfattere Camilla Brørup Dyssegaard \& Michael Søgaard Larsen

Copyright @ $\quad$ C 2014 by Danish Clearinghouse for Educational Research

ISBN 978-87-7684-852-1 (elektronisk udgave)

978-87-7684-853-8

DOI

10.7146/aul.32.36

Publikationsmåned februar 2014

og år

Kontaktadresse

Dansk Clearinghouse for Uddannelsesforskning

Aarhus Universitet

Tuborgvej 164

2400 København NV

Telefon: +4587163942

cbd@dpu.dk

http//:edu.au.dk/forskning/omraader/danskclearinghouseforuddannelsesforskning 


\section{Indhold}

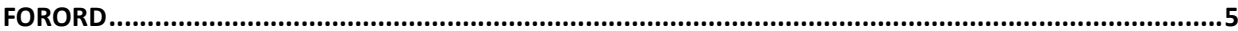

1. EN KORTFATTET SYSTEMATISK FORSKNINGSKORTLAEGING .........................................................

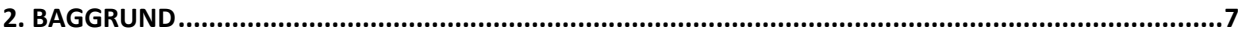

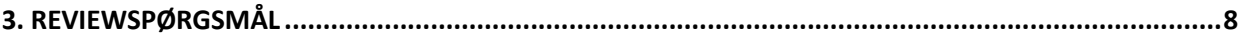

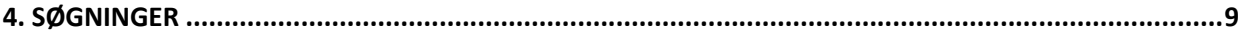

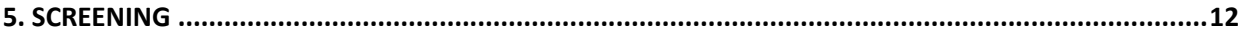

6. FORSKNINGSKORTLAGNING ........................................................................................................12

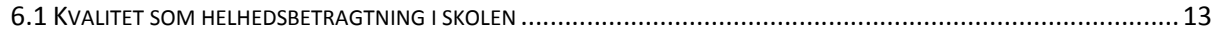

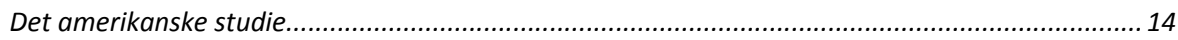

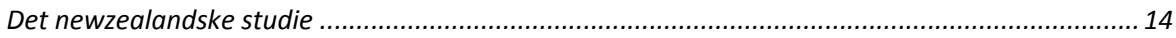

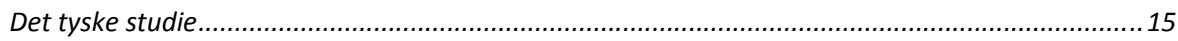

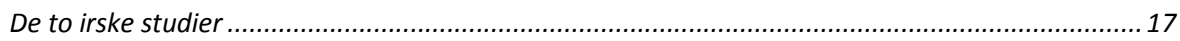

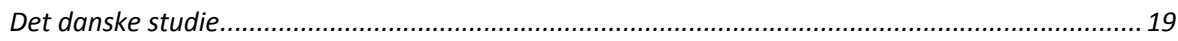

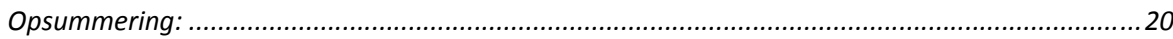

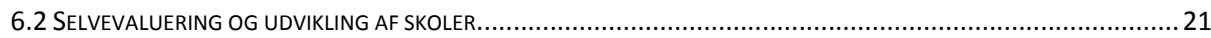

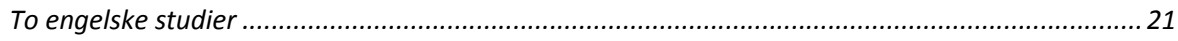

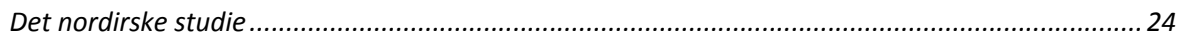

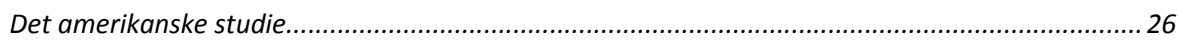

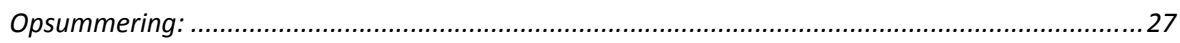

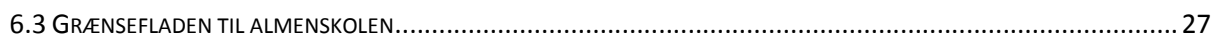

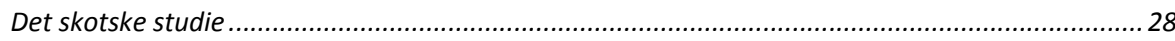

Effekten af inklusion af elever med særlige behov i almenskolen på elevpopulationen $i$

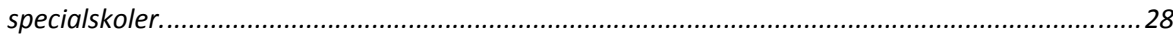

Effekten af inklusion af elever med særlige behov i almenskolen på personalet på specialskoler ...29

Organisering af klassen................................................................................................................ 29

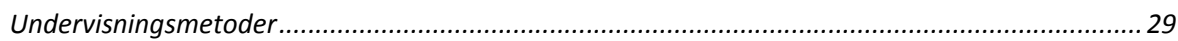

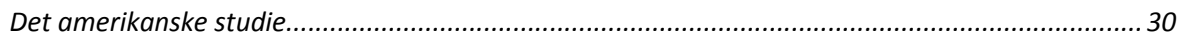

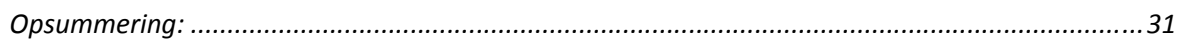

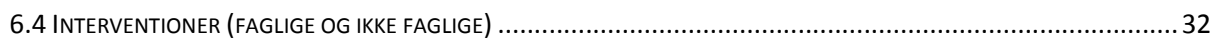

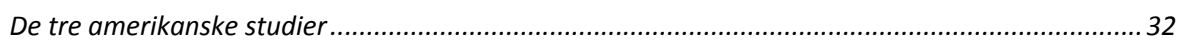

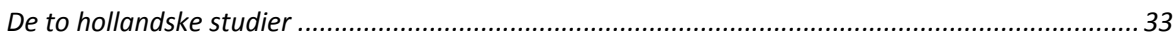

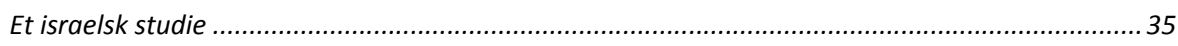

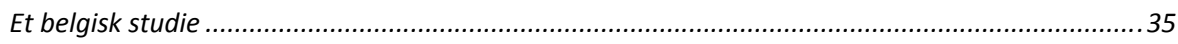

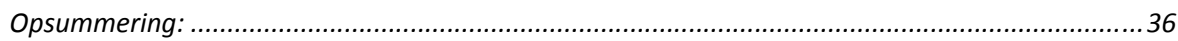




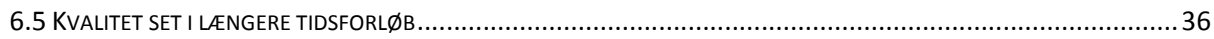

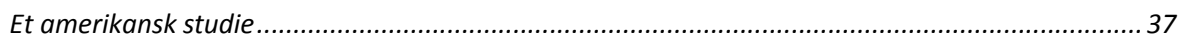

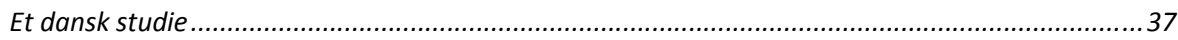

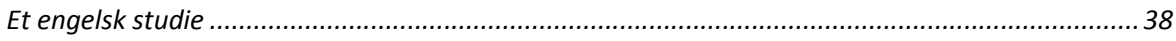

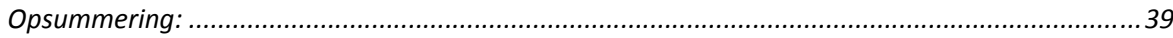

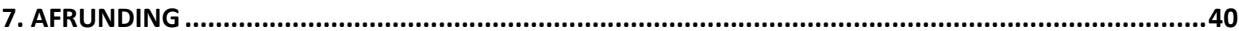

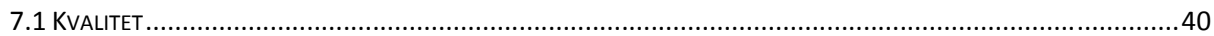

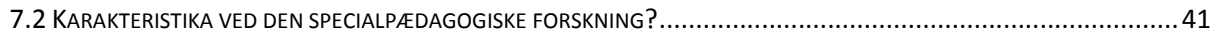

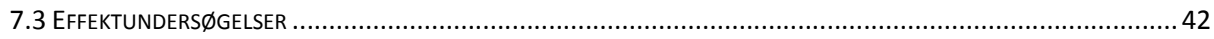

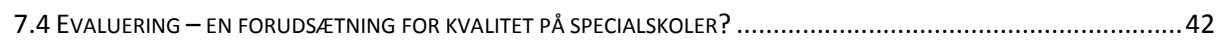

7.5 FAGLIG OG SOCIAL UDVIKLING - ER DET TEGN PÅ GOD KVALITET PÅ EN SPECIALSKOLE? ......................................43

7.6 FORALLDRE- OG ELEVSAMARBEJDE - HAR DET BETYDNING I FORHOLD TIL KVALITET PÅ SPECIALSKOLER? ................... 44

7.7 EVALUERING OG MÅLSAETNINGER FOR HELE SPECIALSKOLEN ER KVALITETSINDIKATORER FOR SPECIALSKOLER ............44

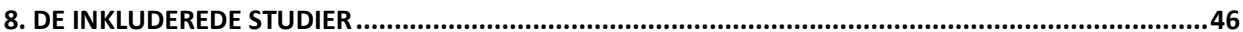

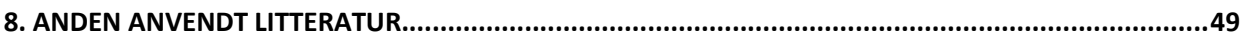




\section{Forord}

Børne- og undervisningsministeriet indgik i december 2012 en aftale om i et forskningsmæssigt samarbejde mellem Aarhus Universitet (Institut for Uddannelse og Pædagogik/forskningsprogrammet SILO) og SFI at gennemføre et projekt, der har til formål at etablere viden om kvalitet på specialskolerne og udvikle kvalitet på skolerne.

Projektet rummer flere dele: Først er der gennemført et review af den internationale forskning om kvalitet på specialskoler, dernæst er der gennemført en survey ved lederne af de danske specialskoler og PPR-enheder. Efterfølgende er der gennemført en registerbaseret analyse af specialskoleelevers resultater af skolegangen. Der er derpå udviklet og afprøvet tre kvalitetsvurderingsværktøjer, og endelig er der beskrevet nogle eksempler på god praksis på danske specialskoler. Der er dermed tale om et meget bredt spektrum af oplysninger om kvalitet på specialskoler, og delene trækker på forskellige metoder, forskningsreview, kvantitative spørgeskemadata, kvantitative registerdata, kvalitative data indsamlet på et seminar og forarbejdet, så de kan anvendes kvantitativt og efterfølgende kvalitativ vurdering og endelig eksempler på god praksis.

De enkelte dele af projektet har hængt sammen på den måde, at reviewet af den internationale forskning sammen med almene demografiske oplysninger og eksisterende kvalitetsindikatorer for folkeskolen har dannet udgangspunkt for konstruktion af de spørgsmål, der indgik i surveyen, samt valget af registerbaserede oplysninger. Med hensyn til eksisterende kvalitetsindikatorer for folkeskolen tænkes på nationale test, afgangsprøver, overgang til ungdomsuddannelse (output). Reviewet har sammen med surveyen og forskellige faglitterære kilder været udgangspunkt for et "fremtidsværksted", der har identificeret kvalitetsindikatorer i specialskoler, som senere er blevet afprøvet og videreudviklet. Det har været centralt for arbejdet med kvalitetsindikatorerne, at de har fo- 


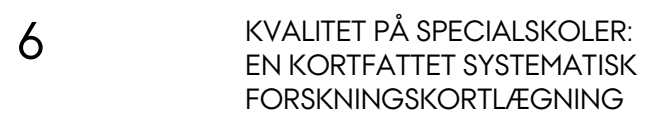

kuseret på at forene specialpædagogik og -didaktik med almen pædagogik og didaktik. Registeranalyserne belyser kvalitetsforhold bagudrettet (output,) og eksemplerne på god praksis kan give inspiration til det fortsatte kvalitetsarbejde på danske specialskoler (proces).

De enkelte dele af projektet er beskrevet i fem rapporter og tre former for kvalitetsudviklingsværktøjer. De fem rapporter er alle udgivet af Institut for Uddannelse og Pædagogik på Aarhus Universitet, hvor de også kan downloades gratis. De tre værktøjer er webbaserede. Følgende giver en oversigt over publikationerne:

Indeværende rapport bringer resultaterne fra reviewet af den internationale forskning.

Dyssegaard, C.B. og Larsen, M.S. (2014): Kvalitet på specialskoler: En systematisk forskningskortlægning. Dansk Clearinghouse for Uddannelsesforskning. Aarhus Universitet

Rangvid, B.S. og Egelund, N. (2014): Faktorer af betydning for kvalitet $i$ specialskoler: En survey-kortlagning blandt specialskoler og PPR. SFI.

Rangvid, B.S. og Lynggaard, M. (2014): Specialskoleelevers resultater ved skolegangens afslutning og fem år senere. SFI

Tetler, S. og Hedegaard-Sørensen, L. (2014): Udvikling af tre kvalitetsudviklingsværktøje.Redegørelse for baggrund og metode - i forhold til udarbejdelsen af de tre kvalitetsvurderingsskemaer. Institut for Uddannelse og Pædagogik (DPU), Aarhus Universitet

Morin. A. (2014): Kvalitetsvurdering af undervisningen i specialskoler - Praksisfortællinger. Institut for Uddannelse og Pædagogik (DPU), Aarhus Universitet

Niels Egelund, projektleder

Februar 2014 


\section{En kortfattet systematisk forskningskortlœegning}

En kortfattet systematisk forskningskortlægning gennemføres hurtigere end en traditionel, fuld systematisk forskningskortlægning, der normalt varer ca. 1/2 år. De processer, der indgår, er de samme, men den totale dækning af et forskningsfelt tilstræbes ikke. Derimod sigtes der mod at ramme kernen af feltets forskning. Alle processer i nærværende forskningskortlægning er som i traditionel systematisk forskningskortlægning forbundet med transparens. Denne 'brief' forskningskortlægning er gennemført på én måned.

\section{Baggrund}

Der sker en omfattende omlægning af de undervisningstilbud, som er rettet mod elever med særlige behov i grundskolen. Regeringens målsætning om at inkludere flere elever betyder, at elevsammensætningen på specialskolerne er under forandring. Samtidig er der med baggrund i en undersøgelse af specialundervisningen $\mathrm{i}$ folkeskolen identificeret et behov for at styrke viden om metoder og effekt af undervisningen i de segregerede undervisningstilbud - specialskolerne.

På baggrund heraf er der udformet et forsøgs- og udviklingsprojekt, der har til formål at udvikle en metode til at styrke kvaliteten af undervisningen i specialskolerne.

Projektet indeholder fem dele, hvor denne kortfattede systematiske forskningskortlægning er det første. 


\section{Reviewspørgsmål}

Hvilke forhold $i$ specialskolen har positive effekter på eleverne?

Hvad gør en specialskole god, eller hvad er god kvalitet på en specialskole?

Forskning, der kan belyse disse spørgsmål, vil blive søgt, screenet, kvalitetsvurderet og beskrevet. Der er på forhånd en forventning om, at der ikke er mange undersøgelser, som direkte besvarer dette spørgsmål. Derfor gennemføres dette review med henblik på at finde forskning, der i bredere forstand belyser dette.

Analysen gennemføres for at understøtte gennemførelse af en senere primærundersøgelse i Danmark af kvalitet i specialskolernes undervisning.

I projektet afgrænses der på denne vis:

Specialskoler er skoler (offentlige eller private) for elever med særlige behov i alderen 5/6 år til 16/17 år, hvor der udelukkende går elever med særlige behov.

Elever er sådanne i 5-/6- til 16-/17-års alderen, der går i specialskoler.

Effekter er virkninger på elever med særlige behov af kognitiv, social eller trivselsmæssig art.

Geografisk indgår EU-landene, øvrige Skandinavien samt USA, Canada, Australien og New Zealand.

Tidsmæssigt afgrænses der med undersøgelser, som er publiceret i 1990 eller senere.

Sprogligt afgrænses der til undersøgelser, der er publiceret på engelsk, tysk eller skandinaviske sprog.

Om en specialskole er god, skal således ses i virkninger på eleverne. Der vil være fokus på forhold, som specialskolen kan gøre noget ved. Som bekendt kan skolerne ikke ændre elevernes etnicitet, sociale baggrund, køn etc. 


\section{Søgninger}

Der gennemføres søgninger i en begrænset, men central mængde af databaser. Alle søgninger er gennemført i uge 4 eller 5 i 2013.

ERIC er verdens største pædagogiske database. Den er international, men har hovedvægt på den amerikanske forskning. Den anvendte søgeprofil er denne:

all(("special school*" OR "special needs school*" OR "special education school*") AND (SU.EXACT.EXPLODE("School Effectiveness") OR SU.EXACT.EXPLODE("Instructional Effectiveness") OR SU.EXACT.EXPLODE("Educational Quality") OR SU.EXACT.EXPLODE("program evaluation")))

Limited by date and document type and education level:

Date: After January 011990

Document type:

041 Dissertations/theses - Doctoral Dissertations, 070 Information Analyses, 073 Eric Digests In Full Text, 142 Reports - Evaluative, 143 Reports Research

Education level:

Elementary education, Elementary secondary education, Grade 1, Grade 10, Grade 2, Grade 3, Grade 4, Grade 5, Grade 6, Grade 7, Grade 8, Grade 9, Intermediate grades, Junior high schools, Middle schools, Primary education, Secondary education

Psycinfo er verdens største psykologiske database. Den er international, men har en overvægt af angloamerikansk forskning. Her er der søgt således:

\begin{tabular}{|c|c|c|}
\hline (SU.EXACT.EXPLODE("Special & Education & Students") \\
\hline SU.EXACT.EXPLODE("Special & \multicolumn{2}{|c|}{ Needs") } \\
\hline U.EXACT.EXPLODE("Special & Education & Teachers") \\
\hline
\end{tabular}




\section{$10 \quad$ KVALITET PÅ SPECIALSKOLER: \\ EN KORTFATTET SYSTEMATISK \\ FORSKNINGSKORTLÆENING}

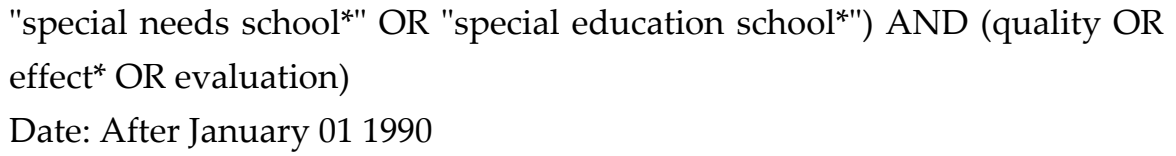

Bibliotek.dk er det danske bibliotekssystem, der indeholder den samlede bogbestand i danske biblioteker.

Der er søgt således:

(specialskole? eller specialundervisning?) og (effekt? eller virkning? eller udbytte? eller kvalitet?) Udgivet efter 1989

Forskningsbase.dk er den nationale danske forskningsdatabase, der for de sidste par år er godt dækkende for dansk forskning. Dækningen tidligere er mere sporadisk. Her er der søgt således:

specialskole?=specialundervisning

DIVA-portal er anvendt til afsøgning af svensk materiale. Den er et dokumentationssamarbejde mellem svenske universiteter om forskningsformidling. Nyere svensk forskning på uddannelsesfeltet er godt dækket i denne kilde. Der er søgt således:

Särskola*

Kun research publications

Kataloget for Jÿväskylä University Library er det finske ansvarsbibliotek for uddannelsesforskning. Der er søgt således:

(special school? <as a phrase> OR särskola?) AND 1990-2013 <publication year>

FIS Bildung er hovedkilden til tysksproget pædagogisk forskning, uanset hvilket land den er udgivet i. Der er søgt således: 
( (Schlagwörter: SONDERSCHULE) und (Schlagwörter: QUALITAET*) ) und (Jahr >1989)

Feltets forskning findes i flere centrale tidsskrifter. Tre af de væsentligste af disse er gennemset for 1994-ff:

International journal of special education 0827-3383 (kun 2001-ff. gennemset)

European Journal of Special Needs Education 1469-591X

Remedial and special education 1538-4756

Det er også blevet overvejet at søge i norsk materiale, men da der ikke har været specialskoler i Norge siden 1992, er dette ikke gennemført.

Disse søgninger resulterede i følgende fund:

\begin{tabular}{|l|l|}
\hline Afsøgt Ressource & Antal unikke hits \\
\hline ERIC & 39 \\
\hline Psycinfo & 226 \\
\hline Bibliotek.dk & 150 \\
\hline Forskningsbase.dk & 67 \\
\hline DIVA-portal & 54 \\
\hline Jÿväskylä University Library Catalogue & 7 \\
\hline FIS Bildung & 135 \\
\hline Tre kernetidsskrifter gennemset & 31 (artikler udtaget) \\
\hline I alt & 709 \\
\hline
\end{tabular}




\section{Screening}

Efter gennemgang af alle 709 referencer resterede 28 referencer, som i bredere forstand kan belyse reviewspørgsmålene. ${ }^{1}$ Referencerne viser hen til 26 forskellige studier.

I screeningen er naturligvis først og fremmest ekskluderet de referencer, som ved nærmere eftersyn ikke viste sig at handle om specialskoler. Under screeningen er desuden ekskluderet det, der i sin form ikke har karakter af empirisk primærforskning eller systematisk review, fx diskussioner, teoretiske bidrag, betænkninger, historiske redegørelser etc. Ligeledes er der ekskluderet undersøgelser af specialskoler med et rent deskriptivt sigte. Dvs. sådanne, som alene går ind i, hvad der foregår på skolen. Undersøgelser, der sammenligner forholdene i henholdsvis almenskole og specialskole, er også ekskluderet, idet disse sjældent kan give viden om de forhold i en specialskole, der kunne gøre den god.

Alle søgehits er uploadet og gemt i Endnote, hvor screeningen også har fundet sted.

De undersøgelser, som er inkluderet, belyser direkte effekten af specialskolens indsats eller kommer ind derpå ved på forskellig vis at undersøge kvaliteten af specialskolen.

\section{Forskningskortlœgning}

Der er altså 26 undersøgelser, som kan belyse spørgsmålet om kvalitet eller effekt af specialskoler.

Det er bemærkelsesværdigt få undersøgelser, der findes på dette felt. Dette i empirisk forskning at betragte specialskolen under effekten eller kvalitetens synsvinkel er altså overordentlig sjældent.

\footnotetext{
${ }^{1}$ Det har ikke været muligt inden for den måned, der har været til rådighed for kortlægningen, at skaffe tre af de 709 fundne referencer.
} 
De 26 studier, som kan belyse vort reviewspørgsmål, kan kort karakteriseres således:

Studierne fordeler sig på oprindelsesland således: USA syv, England fire, Irland tre, to fra hvert af landene Holland, Sverige, Tyskland og Danmark, et fra hvert af landene Skotland, Belgien, Israel og New Zealand.

Studiernes primære forskningsdesign fordeler sig således: ti surveys, fire followupstudier, tre eksperimentelle design, tre casestudier, to kvalitative design, to mixed methods, én validitetstest af materiale, et korrelationsstudie.

Studiernes omfang: Nogle få af de survey, der indgår i materialet, er baseret på større datamængder, men studierne er oftest - uanset deres design - baseret på en mindre datamængde.

Der er også foretaget en vis vurdering af forskningens rapporteringskvalitet. Det viste sig her, at tre af undersøgelserne (ingen af disse peer reviewed) var rapporteret på en sådan måde, at der ikke kunne fæstes lid til deres resultater. I to tilfælde var der tale om undersøgelser med et uforholdsmæssigt stort frafald i den undersøgte population, hvor der ikke blev redegjort tilfredsstillende for dettes virkning på resultaterne. Den sidste undersøgelse kan der ikke fæstes lid til, fordi den i sin rapportering af et i øvrigt relevant forsøgsarbejde sammenblander indsats og virkning og meninger om virkninger og dermed ikke kan give pålidelige resultater.

Tilbage er derefter 23 studier, der kan belyse reviewspørgsmålet.

Disse studier er herefter tematisk opdelt i fem temaer: Kvalitet som helhedsbetragtning i specialskolen, selvevaluering og udvikling af skoler, grænsefladen til almenskolen, interventioner, kvalitet set i et længere tidsforløb.

\subsection{Kvalitet som helhedsbetragtning i skolen}

De syv studier i denne kategori undersøger på forskellig vis kvalitet i specialskolen som helhed. Dvs., at mere overordnede betragtninger knyttet til dette er i fokus.

Geografisk fordeler studierne sig således: et fra USA, et fra New Zealand, et fra Tyskland, et fra England, to fra Irland og et fra Danmark. 


\section{Det amerikanske studie}

Lehr et al. (2009) har publiceret en stor undersøgelse fra USA med dels analyse af staternes (forskellige) lovgivning og policy, dels en survey om specialskolerne i USA. Metodisk er studiet gennemført som en kombination af dokumentstudier og interviews. Undersøgelsen redegør deskriptivt for en mængde forskellige forhold på specialskolefeltet i USA.

Feltet synes tæt lovgivningsreguleret, hvad angår bestemmelse og funktion af specialskoler, hvem der kan være elever og lærere der, og hvad der skal være skolernes læreplaner. I praksis kan det imidlertid konstateres, at elevernes udbytte af specialskoleopholdet i faglig og anden henseende på kort eller langt sigt kun sjældent dækkes. Data om elevstrømme frem og tilbage mellem almenskole og specialskole er ligeledes sjældent til rådighed. Denne undersøgelse kan dermed alene bidrage med viden om ringe udbredelse af kvalitetsvinklen på specialskolernes indsats.

\section{Det newzealandske studie}

En surveyundersøgelse af Pickering $\mathcal{E}$ Wilton (1996) omfatter 29 newzealandske specialskoler med i alt 1.498 elever. Der er spørgeskemasvar fra 1.073 forældre og 469 lærere. Undersøgelsen kan bidrage med viden om lærere og forældres syn på specialskolernes tilbud.

Undersøgelsen viser en stor forældretilfredshed med skolernes tilbud, idet $86 \%$ af alle forældre fandt, at specialskolen imødekom deres barns behov. Der blev konstateret stor kongruens mellem forældrenes og lærernes synspunkter. Forældrenes hyppigst anførte grunde til placering af barnet i specialskolen var: en passende læreplan, adgang til speciallærere, adgang til et trygt miljø, det var den eneste mulighed.

De fleste forældre svarede nej på spørgsmålet, om de havde overvejet at sende deres barn i en almenskole. Kun en mindre del af forældrene kunne for deres barn se positive sider ved inklusion i almenskolen. Ca. halvdelen af forældrene ville under ingen omstændigheder have deres barn inkluderet $\mathrm{i}$ almenskolen.

Denne newzealandske undersøgelse kan således bidrage med et øjebliksbillede af forældres mening om deres barns specialskole. 


\section{Det tyske studie}

Beyer (2009) undersøger i sin doktorafhandling forholdene på specialskoler for blinde og svagtseende i Tyskland. I undersøgelsen indgår data fra 34 skoler, bl.a. i form af interviews med 34 skoleledere og 36 undervisere. Studiet er i sit design kvalitativt. Undervisningskvalitet og skolekvalitet er centrale momenter både $\mathrm{i}$ afhandlingens principielle diskussion og i dens empiriske undersøgelse. Afhandlingen ser kvalitet som en positiv konnoteret, men relativ egenskab ved et fænomen, der kun kan reflekteres over, hvis den forud er defineret.

Spørgsmålet, om kvalitet er eller kan være én og samme egenskab ved almenskoler og specialskoler, stilles og besvares af skoleledere og lærere fra specialskolerne. Findes der med andre ord en særlig specialskole-kvalitet, som er anderledes end almenskolens kvalitet? Skolelederne og lærerne giver i denne undersøgelse deres bud på, hvori den gode kvalitet består, hvordan den skabes, og hvordan den viser sig. Undersøgelsen sigter dermed på at give et empirisk funderet billede af skolernes egne forestillinger om kvalitet.

Undersøgelsen finder frem til en kerne i forestillingerne om den gode undervisning på blindeskolerne.

Vigtigst i forestillingen om den gode undervisning er individualisering, der er forbundet med flere pædagogiske kerneprocesser: diagnostik af læringens udgangspunkt, valg af undervisningsindhold og -former, tilpasning af medier, realisering af supplerende læringsindhold for blinde og svagtseende, stofformidling tilpasset kontakten til barnet.

Den gode undervisning er også karakteriseret ved faktorerne: skoleatmosfæren, elevens glæde ved at lære noget og elevernes trivsel. Det kan konstateres, at elevens glæde ved at lære noget vurderes som vigtigere end deres faktiske læringsresultater. Et skolekulturforhold som skolens orientering mod elevernes faglige præstationer var ikke tildelt nogen fremtrædende rolle i forestillingerne om kvalitet.

Videre i lærernes og ledernes karakteristik af den gode specialskole spillede samarbejdet mellem lærere og mellem lærere og ledelse også en stor rolle. Beyers analyse peger således på, at når skolerne betragtes indefra, er god kvalitet noget specifikt for disse. Almenskolers forestillinger om kvalitet er ikke umiddelbart slået igennem her. 


\section{KVALITET PÅ SPECIALSKOLER: \\ EN KORTFATTET SYSTEMATISK \\ FORSKNINGSKORTLÆGNING}

Herunder kan ses Beyers optimerede model over undervisningskvalitet på specialskoler for blinde og svagtseende. Bemærk at modellen er optimeret, hvilket bl.a. ses af at fagligt læringsudbytte er indsat.

\begin{tabular}{|c|c|c|c|c|c|}
\hline \multirow{10}{*}{ 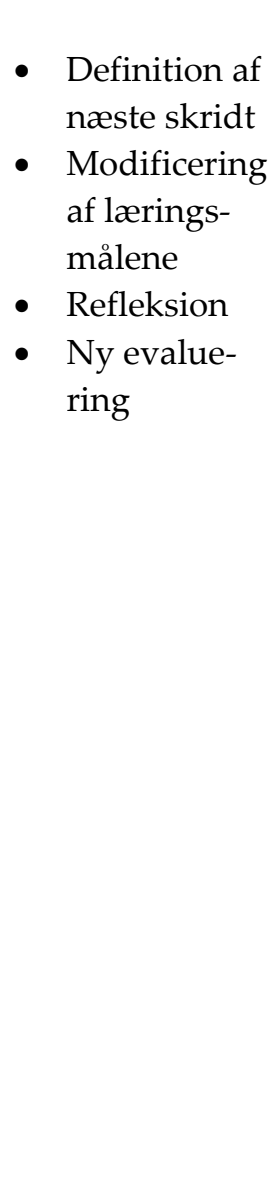 } & \multirow{9}{*}{$\leftarrow$} & \multirow{2}{*}{\multicolumn{3}{|c|}{$\begin{array}{l}\text { Vellykket skolegang/ mestring: } \\
\text { Faglige kompetencer } \\
\text { Handicapspecifikke kompetencer } \\
\text { Sociale kompetencer }\end{array}$}} & \multirow{10}{*}{$\begin{array}{l}\uparrow \\
\text { leder } \\
\text { til/ mu- } \\
\text { liggør }\end{array}$} \\
\hline & & & & & \\
\hline & & \multirow{2}{*}{\multicolumn{3}{|c|}{$\begin{array}{l}\text { Positivt forhold til barnet } \\
\text { Positiv indlæringsatmosfære i skolen og klassen }\end{array}$}} & \\
\hline & & & & & \\
\hline & & \multicolumn{3}{|c|}{$\begin{array}{l}\text { Tilrettelæggelse af individuelle læringsmiljøer i } \\
\text { fællesskab }\end{array}$} & \\
\hline & & \multicolumn{3}{|c|}{$\begin{array}{l}\text { Stille individuelt tilpassede medier til rådighed/ } \\
\text { sætte eleven i stand til at bruge hjælpemidler }\end{array}$} & \\
\hline & & \multicolumn{3}{|c|}{$\begin{array}{l}\text { Reflekteret valg af undervisningsformer og un- } \\
\text { dervisningens indhold (kriterier: relation til } \\
\text { barnets konkrete verden, yderligere blindepæ- } \\
\text { dagogiske indlæringsmål og uddannelsesind- } \\
\text { hold) }\end{array}$} & \\
\hline & & \multicolumn{3}{|c|}{$\begin{array}{l}\text { Evaluering af barnets indlæringsmæssige ud- } \\
\text { gangsposition: præstationsniveau, funktionelt } \\
\text { syn, socio-emotionelle behov }\end{array}$} & \\
\hline & & $\begin{array}{l}\text { Samarbejde } \\
\text { med kolle- } \\
\text { gaer }\end{array}$ & $\begin{array}{l}\text { Blindepædago- } \\
\text { gisk faglighed } \\
\text { og kvalifikation }\end{array}$ & $\begin{array}{l}\text { Samarbejde } \\
\text { med forældre- } \\
\text { ne }\end{array}$ & \\
\hline & $\longrightarrow$ & \multicolumn{3}{|c|}{ Specifikke fysiske forhold og personaleforhold } & \\
\hline
\end{tabular}

(Beyer, s. 347)Det engelske studie

Siden 1998 har det været lovbestemt, at alle børn skal vurderes, når de er ca. fem år gamle, uanset om de går i almen- eller specialskole. I Lewis at al. (2003) sætter de spørgsmålstegn ved, om denne baseline-vurdering overhovedet har værdi eller validitet i forhold til børn med særlige behov. Studiet er en survey. Studiet omfatter data fra 982 skoler i England, hvoraf 107 er specialskoler. Ses 
der udelukkende på de 107 specialskoler, blev der benyttet 42 forskellige baseline-vurderingssystemer. Alle vurderingssystemer skal leve op til kriterierne for vurdering opstillet af regeringen.

Resultaterne viser, at der er stor forskel på, hvilke områder der vægtes i vurderingssystemerne mellem almen- og specialskolerne. Specialskolerne målte fx på kreativ udvikling, det talte sprog, viden om og forståelse af verden og fysisk udvikling. Til gengæld var det mindre sandsynligt, at specialskolerne målte på problemløsning, social adfærd, selvstændighed, koncentration, motivation for læring og receptivt sprog. Fx var det $2 / 3$ af alle almenskoler, der vurderede elevernes evne til at koncentrere sig, hvor blot 2/5 af specialskolerne vurderede koncentrationsevnen. Der er en markant forskel på, hvilke evner der skal vurderes i forhold til de to elevgrupper.

Formålet med at foretage baseline-vurderinger på almenskolerne er at sikre, at elever kan det, de skal kunne. Disse vurderinger har karakter af screeninger. På specialskolerne er eleverne i forvejen systematisk testet i forbindelse med placering på specialskole. Det interessante i resultaterne af surveyen er den markante forskel, der er på vægtningen af forskellige færdigheder blandt elevgrupperne. Almenskolerne vægter vurdering af kognitive færdigheder, medens specialskolerne vægter det konkret handlende.

\section{De to irske studier}

I studiet fra Nordirland Dobbins $\mathcal{E}$ Abbott (2010) var formålet at se på, hvordan samarbejdet mellem specialskole og forældre fungerede. Studiet, der har et mixed methods-design, blev valgt til at belyse forældrenes holdning og syn på skole-hjem-samarbejdet. Data blev indsamlet på én specialskole.

Resultaterne blev organiseret i temaer, som relaterede til forskningsspørgsmålene: Holdninger til forældre-lærere-samarbejdet, hæmmende faktorer indenfor samarbejdet og forbedring af forældre-lærere-samarbejdet.

Resultaterne viser, at der var bred enighed blandt forældrene om, at samarbejdet var meget vigtigt, og at det værdsattes højt. Det ses dog også af data, at forældre kan føle, at samarbejdet er støttende, men at det til tider også kan opleves som et stressmoment. Tre områder til forbedring fremstod tydeligt $\mathrm{i}$ analysen: kommunikation, forældreengagement og udvikling af samarbejdet. 
Det fremgår, at forældrene har et ønske om at have et større kendskab til, hvordan skolen tilgodeser deres barns behov. Skole-hjem-samarbejdet reduceres, når skolens "viden om barnet" synes at være det "eneste" rigtige. Hvis forældrenes viden om barnet ikke inddrages, vil samarbejdet og dets effektivitet $\mathrm{i}$ forhold til at møde barnets behov blive reduceret markant.

På trods af at dette er en mindre undersøgelse, er der nogle resultater, som er interessante $\mathrm{i}$ forhold til at vurdere en specialskoles kvalitet. Skolernes strategier og praksis skal revideres, således at der sikres gensidigt samarbejde mellem forældre og lærere. Planlægningen af en specialelevs undervisning og læring vil blive mere succesfuld, hvis den bygger på både forældrenes og lærernes viden om barnet.

Ifølge irsk lovgivning skal skoler indgå et samarbejde med forældrene. Udgangspunktet for samarbejdet skal være ligeværdigt. Specialskoler har en udfordring på dette punkt, da forældregruppen er sårbar og har haft tradition for at overlade ansvaret for deres børns læring til skolerne. Metoder og teknikker til at udbygge dette samarbejde er væsentlige, hvis en bedre kvalitet i forældresamarbejdet skal opnås.

Kelly et al.s (2007) studie er et surveystudie. Surveyens spørgsmål blev sendt ud til samtlige ledere af specialskoler i Irland ( $n=111)$, hvor 67 \% (n=74) af lederne svarede. Surveyen blev fulgt op af en række interview med tilfældigt udvalgte skoleledere. Formålet med studiet var at undersøge kilder til stress hos skoleledere på specialskolerne og effekten af at skulle håndtere udfordrende adfærd. Skolelederne vurderede graden af stress og potentielle stresskilder i forhold til at takle elever med udfordrende adfærd. Der blev endvidere set på, hvor ofte skoleledernes aktiviteter blev afbrudt af episoder med udadreagerende adfærd , og på virkninger på både lærere og andre elever.

Resultaterne viste, at det stresser skolelederne at håndtere tilfælde af udadreagerende adfærd. Episoderne resulterede endvidere i, at skolelederne ofte fik afbrudt deres ledelsesarbejde, og at tilfældene i øvrigt påvirkede indlæringen hos både eleverne med den udadreagerende adfærd og hos de andre elever. Skolelederne var meget bekymrede for deres personales sikkerhed og ligeledes for, hvordan de kunne sikre et effektivt undervisningsmiljø. 
Det fremhæves endvidere, at et kvalitetskriterium for en specialskole også burde handle om, hvordan elever med denne type vanskeligheder bedst tilgodeses på skolerne - både af hensyn til egne og andres læring og til personalets overordnede trivsel.

\section{Det danske studie}

I 2002 satte Undervisningsministeriet og EVA en evaluering i gang af den ændrede opgavefordeling mellem amt og kommune med hensyn til den vidtgående specialundervisning, herunder KVIS-programmet (KValitet I Specialundervisningen). I evalueringen indgår en survey, hvor lærere spørges om aspekter ved de otte kvalitetsindikatorer, som er udarbejdet i forbindelse med KVISprogrammet.

KVIS-programmets otte kvalitetsindikatorer:

1. Individuel tilrettelæggelse og gennemførelse af undervisningen

2. Forældre-skole-samarbejde

3. Skoleindretning og undervisningsmidler

4. Leder- og lærerkvalifikationer

5. Overgang fra grundskole til fortsat uddannelse og beskæftigelse

6. Samordnet indsats skole-fritid

7. Småbørn

8. Ansvars- og opgavefordeling, formidling af viden.

I nedenstående tabeller ses resultaterne fra lærernes survey, hvor de blev bedt om at tage stilling til, i hvilken grad de oplevede, at de otte kvalitetsindikatorer forsøgtes indført på deres skoler: 


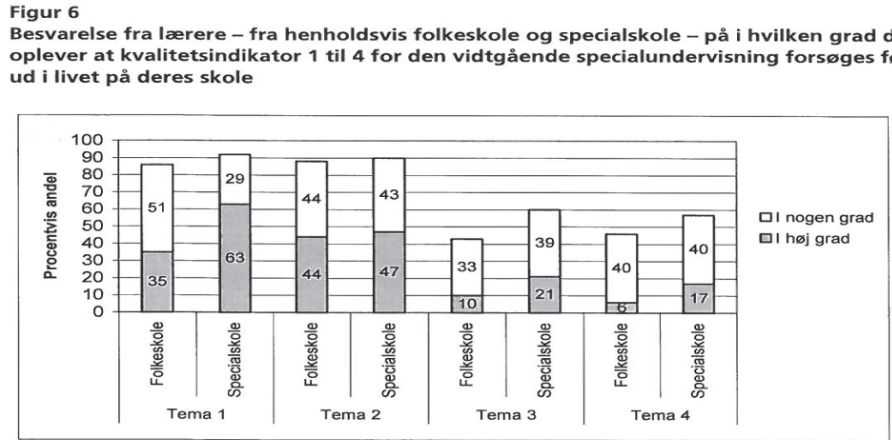

Tema 1: individuel tilrettelæggelse og gennemførelse af undervisningen, tema 2: forældre-skole-samarbejde, tema 3: skoleindretning og undervisningsmidler, tema 4: leder-og lærerkvalifikationer.

(EVA, 2003, s. 81)

Figur 7

Besvarelse fra lærere - fra henholdsvis folkeskole og specialskole - på i hvilken grad de oplever at kvalitetsindikator 5 til 8 for den vidtgående specialundervisning forsøges ført ud i livet på deres skole

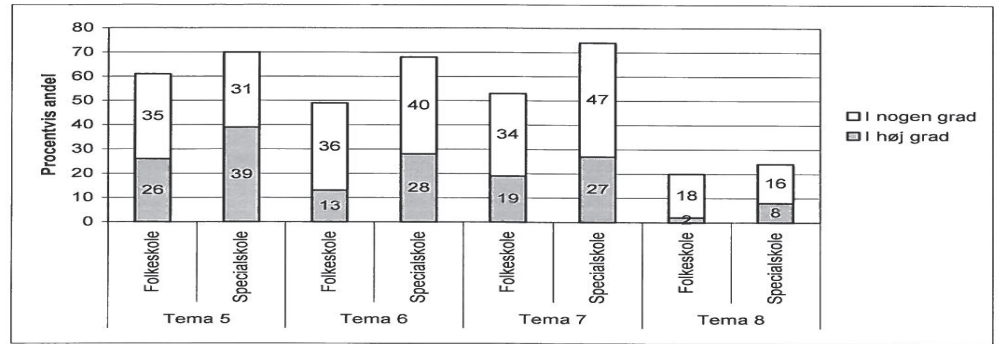

Tema 5: overgang fra grundskole til fortsat uddannelse og beskæftigelse, tema 6: samordnet indsats skole-fritid, tema 7: småborn, tema 8: ansvars- opgavefordeling, formidling af viden.

(EVA, 2003, s. 82)

Det ses af resultaterne, at speciallærere fra specialskoler i højere grad end speciallærere i almenskolen vurderer, at arbejdet med kvalitetsindikatorerne søges ført ud i livet på skolerne.

\section{Opsummering:}

Studierne om kvalitet set i det større specialskoleperspektiv peger tilsammen på: 
- Der er ringe udbredelse af synspunktet, at specialskolerne skal dokumentere deres resultater. Data om elevers faglige udbytte eller data om overgange mellem almenskole og specialskole er ikke sædvanligvis til rådighed. Specialskolerne lægger mindre vægt på det kognitive udbytte og mere vægt på det konkret handlende.

- Hvis forældre til specialskoleelever spørges om kvaliteten af specialskolen, udtrykker de stor tilfredshed med kvaliteten.

- Hvis skoleledere og lærere på specialskoler spørges om, hvad der er god kvalitet, viser der sig forestillinger, som ikke er identiske med dem, der mødes i almenskolen. Væsentligst i forestillingerne er individualisering, skoleatmosfæren, elevens glæde ved at lære noget og elevernes trivsel.

- Forældrenes viden om barnet kan med fordel indgå ved siden af skolens viden om barnet i tilrettelæggelsen af god undervisning.

- Skolernes kompetence i håndtering af udadreagerende elever er afgørende både i forhold til personalets og ledelsens trivsel og elevernes læring.

\subsection{Selvevaluering og udvikling af skoler}

Der er fem referencer, fire studier $\mathrm{i}$ alt, der har set på betydningen af skoleinspektioner og skolens fortsatte udvikling på baggrund af inspektionsrapporterne. Der er to studier fra England, et fra Nordirland og et fra USA. Fælles karakteristika for disse studier er, at de evaluerer virkningen af statslige inspektioner af specialskoler og de efterfølgende handlingsplaner, som udarbejdes på baggrund af inspektionsrapporten. Disse studier kan bidrage med svar på, hvordan specialskoler kan udvikle en evalueringspraksis, som kan bidrage til bedre kvalitet.

\section{To engelske studier}

De to studier tager udgangspunkt i effekten af OFSTED-inspektioner på udviklingen af specialskolers kvalitet. OFSTED står for Office for Standards in Education. Formålet med inspektionerne er, at skolerne bliver evalueret af en ekstern, 
uafhængig konsulent i forhold til kvaliteten af elevernes læring. Konsulenter evaluerer skolens effektivitet og giver en vurdering af, hvad skolen skal gøre for at forbedre sine resultater.

Undersøgelsen af Thomas et al. (2000) og Davies et al. (1999) har set på, hvad det er, der gør, at specialskoler i højere grad end almenskoler sættes under special measures efter en inspektion $(7,6 \%$ af specialskolerne og $2 \%$ af almenskolerne). Special measures betyder: Specielle tiltag skal sættes $i$ værk, fordi skolen ikke formår eller formentlig ikke formår at give eleverne et acceptabelt uddannelsesniveau.

58 specialskoler indgår i studiet, hvilket på det tidspunkt var næsten samtlige specialskoler i England (tre kom ikke med, da der ikke fandtes tilstrækkeligt med data), som var sat under special measures. Samplet repræsenterer et bredt udsnit af de forskellige typer specialskoler med undtagelse af skoler for elever med socio-emotionelle vanskeligheder - halvdelen af disse skoler er sat under special measures. Thomas et al. (2000) skulle i studiet identificere, hvordan specialskolerne sat under special measures benyttede post-inspektionsplanen til at udarbejde en handlingsplan som udgangspunkt for en forbedring af skolen, og i hvilket omfang disse planer resulterede i en kvalitetsforbedring på skolerne. Der blev foretaget en komparativ analyse af de specialskoler, der formåede at forbedre sig, så de kom ud af special measures- tilsynet, og de specialskoler, som forbedrede sig mindst.

Resultaterne viser en sammenhæn mellem skolernes forbedring og kvaliteten af handlingsplanen. Der ses en tendens til, at de skoler, som klarede sig dårligst, havde de mindst udførlige planer. Det nævnes endvidere, at manglen på rådgivning fra den lokale forvaltning eller konsulenter typisk medførte begrænset støtte til implementeringen af planen. Det hævdes, at dårlig støtte fra forvaltning og konsulenter kan føre til en mindre præcis og målrettet plan og til en inkonsekvent monitorering og evaluering af planen, hvilket afstedkom en langsommere forbedringsproces.

Planerne for de skoler, der viste en positiv udvikling, blev sammenlignet med planerne for de skoler, som viste en begrænset eller meget begrænset udvikling. Der er tre områder, som er bemærkelsesværdigt forskellige i planerne: 
- En præcisering af personligt ansvar for handlinger - de skoler, som udviklede sig positivt, havde en tydelig ansvarsfordeling

- En handlingsplan for opfølgning på, om planen virker - de skoler, som klarede sig bedst, havde en tydelig plan for monitorering og evaluering

- En tydelig definition af, hvilke handlinger der skulle sættes i gang.

De komparative profiler viser, at alle specialskolerne havde det til fælles, at det var meget vanskeligt for dem at udarbejde mål, som efterfølgende kunne evalueres. Forholdet mellem en handlingsplans kvalitet og en forbedring af skolen afhænger ikke kun af at kunne sætte præcise mål, men også af, at der bl.a. tages stilling til, hvem der skal gøre hvad og hvornår, og hvordan der løbende kan følges op på planen og dens effekt.

Der blev endvidere foretaget en sammenligning mellem de fem skoler, som viste størst fremgang, og de fem skoler, der viste mindst fremgang. Den største forskel, der blev fundet, var i forhold til det at anvende eksternt personale. Skolerne med mindst fremgang benyttede slet ikke eller i meget begrænset omfang eksterne konsulenter i forbindelse med planlægning og monitorering, hvor skolerne med størst fremgang benyttede en række eksterne rådgivere og konsulenter til planlægning, monitorering og implementering af planen. Skolerne med størst fremgang benyttede rådgivere og konsulenter i over halvdelen af deres planlagte aktiviteter, hvad de andre skoler gjorde i et meget begrænset omfang. Analyse af data fra casestudier på udvalgte specialskoler viser, at kvaliteten af den støtte, som skolerne får i forhold til at implementere handlingsplaner, er afgørende. Det fremhæves af både medarbejdere og ledere, at de har behov for rådgivning og støtte indenfor seks områder:

1. Læseplan og undervisningsstrategier

2. Teknisk støtte til de processer, som følger efter en inspektion

3. Hjælp til at mobilisere støtte

4. Specialistrådgivning: planlægning og tilrettelæggelse af undervisning for de specifikke elevgrupper på specialskolen

5. Moralsk støtte

6. Rådgivning om finansiering og personale. 


\section{KVALITET PÅ SPECIALSKOLER: \\ EN KORTFATTET SYSTEMATISK \\ FORSKNINGSKORTLÆGNING}

Der ses en tydelig sammenhæng mellem de seks nævnte områder og skolernes udvikling. På skolerne, som udviklede sig positivt, havde den lokale forvaltning udformet en plan for støtte til skolerne, hvor de seks nævnte støttebehov indgik, og der var en tydelig fordeling af opgaverne, hvor fx én konsulent indgik som en moralsk støtte og andre som specialister indenfor læseplanen.

Males (2006) studie er et casestudie, der har fulgt en enkelt britisk specialskole både før, under og efter en OFSTED-inspektion. Formålet med studiet var at undersøge speciallæreres oplevelse af stress, helbredstilstand, arbejdsmængde og arbejdsrelaterede følelser før, under og efter endt inspektion. Ud af 17 lærere på skolen indvilligede $14 \mathrm{i}$ at deltage i undersøgelsen.

Data viser, at lærerne betragtede den kommende inspektion med stigende bekymring og fandt processen meget stressende. Arbejdsmængden steg, jo nærmere inspektionen kom, og tiden før inspektionen karakteriseres med en tiltagende negativ følelse overfor jobbet og en følelse af dårligere personlige resultater. Skolen fik en positiv bedømmelse, hvorefter lærerne fik en større jobtilfredshed og en oplevelse af positive personlige resultater. På trods af dette er lærerne ikke positivt indstillede overfor OFSTED-inspektionerne og den eksterne udarbejdelse af en handlingsplan.

Lærerne ønsker en alternativ model for udarbejdelsen af handlingsplaner, der bygger på selvevaluering og omfatter et rådgivende element. Analyserne peger i retning af, at lærerne har behov for at få et større kendskab til målet for inspektionen - undervisningskvalitet og læring - lærerne skal for det første kunne definere, hvilke prioriteringer de har for ændringer og udvikling, og for det andet kunne sætte realistiske og opnåelige mål for en udvikling af skolen. Det væsentlige er, at lærerne skal føle sig som en del af løsningen og ikke en del af problemet.

\section{Det nordirske studie}

I Nordirland er der en bevægelse væk fra de officielle eksterne inspektioner mod en "Quality Assurance Inspection", som er designet til at opfordre skoler til at arbejde med selvevaluering af deres praksis.

Neil et al. (2001) er et casestudie på en specialskole i Nordirland. Formålet med forskningen var at fremme en proces på skolen, som kunne gøre skolen i 
stand til at tage ansvaret for egen udvikling og læring. Lærerne skulle blive i stand til at reflektere over egen undervisning som en måde at forbedre kvaliteten af undervisning og læring på i skolen som helhed.

I studiet deltog 27 lærere. Lærerne skulle i en fire ugers periode udfylde forskningsjournaler med det formål at kunne måle kvaliteten af undervisningen og læringsresultater. Journalen blev designet således, at den gav både lærere og elever mulighed for at give oplysninger om deres undervisning og læring. Journalen skulle på samme tid give deltagerne mulighed for at reflektere over og fortolke deres egen praksis. Kategorierne i journalen blev defineret i samarbejde med lærerne, således at de var let forståelige og relevante for både lærere og elever og kunne bruges til at vurdere den enkelte undervisningstime.

Når lærerne skulle evaluere deres egne resultater, skulle de reflektere over følgende spørgsmål, som fokuserer på professionel udvikling:

- Veksler du mellem mange forskellige former for undervisning, eller holder du dig primært til to eller tre undervisningsformer?

- Udfordrer din undervisning forskellige niveauer af intellektuel karakter? Kan din undervisning udbygges til at inkludere flere kognitive resultater, som passer til dit fag?

- Arbejder skolen som helhed på at arrangere undervisningen således, at eleverne opfordres til at benytte selvstændige læringsstrategier, så eleverne har et medansvar for deres læring?

- Passer dine synspunkter til skolen som helhed?

- Er der stor forskel på pædagogikken og kognitive resultater blandt lærerne på skolen?

Resultaterne fra studiet peger i retning af, at journalmetoden er en anvendelig metode til at vurdere forskellige aspekter af undervisning og læring samt skolen som et læringsmiljø.

På baggrund af resultaterne af de indsamlede data besluttede skolen at sætte fokus på to områder for skolens fortsatte udvikling:

Undervisning og læring: Lærerne blev opmærksomme på, at lærerstyret undervisning var dominerende. I fremtiden skal pædagogiske udviklingsdage sætte fokus på læring og på hvilken type aktiviteter, eleverne sættes i gang 


\section{KVALITET PÅ SPECIALSKOLER: \\ EN KORTFATTET SYSTEMATISK \\ FORSKNINGSKORTLÆGNING}

med. Elevernes uddannelsesplaner skal udbygges med, at der skal arbejdes mod mere selvstændige læringsstrategier.

Skolen som læringsmiljø: Lærerne skal blive bedre til at lære af hinanden og dele effektfulde undervisningsmetoder og mere generel professionel viden. Et kollegialt læringsmiljø skal udvikles ved blandt andet at benytte teamundervisning som en metode til at sikre professionel læring og til at monitorere kvaliteten af undervisningen og læringen.

Resultatet af at have deltaget i forskningen viser, at lærerne har lært at reflektere over deres praksis og analysere deres undervisning i forhold til elevernes læring. Denne måde at selvevaluere på er med til at skabe mulighed for skolefokuseret udvikling, hvor data fortolkes af skolen, og handlings- og udviklingsplaner udarbejdes til gavn for kvalitet i elevernes læring.

\section{Det amerikanske studie}

Det amerikanske studie er en ph.d.-afhandling af Thurston (1998) og er et casestudie. Thurston udviklede og gennemførte et evalueringsprogram til et socialt udviklingsprogram for elever med socio-emotionelle vanskeligheder på en privat specialskole i USA. Det primære fokus i ph.d.-afhandlingen er på programevalueringsprocessen, og formålet er at vise, hvordan praksisudøvere kan designe og implementere et systematisk evalueringsprogram specifikt for elever med socio-emotionelle vanskeligheder i skoler.

Resultaterne viser, at programevaluering af specialpædagogiske undervisningsprogrammer kan resultere i nyttig viden for skolens professionelle og for nøglepersoner inklusive forældre. Der fremhæves flere faktorer, der skal tages højde for, når et specialpædagogisk program skal iværksættes.

Programmet skal relateres direkte til elevernes særlige behov. Elevernes behov skal være eksplicit vurderet og gjort rede for, således at målene for programmet er relevante. En evalueringsplan skal udarbejdes samtidig med selve programmet. På denne måde evalueres programmet direkte i relation til, om eleverne har opnået de fastsatte mål.

Nøglepersoner og grupper på skolen skal deltage i udarbejdningen af programevalueringen. Ifølge analysen af resultaterne resulterer dette i: at der vil være mindre modstand både før, under og efter evalueringen, at motivatio- 
nen til at få indsamlet de nødvendige data vil være større, og at resultaterne af evalueringen vil blive benyttet. Ved at have en aktiv medindflydelse på udarbejdningen af programmet og evalueringen af det skabes der en større motivation for at evaluere programmer fremover.

\section{Opsummering:}

Der er i Danmark ikke et tilsvarende statsligt inspektionssystem som OFSTED eller det formelle irske evalueringssystem, ej heller er der tradition for en systematisk evaluering af egen praksis, skolens udvikling eller effekten af specifikke pædagogiske programmer. De fire studier kan dog bidrage med nogle væsentlige indikatorer for, hvordan en evalueringskultur kan etableres på den enkelte skole, samt noget viden om, hvordan skoler kan arbejde med en kontinuerlig kvalitetsudvikling af deres praksis:

- Støtte til etableringen af læseplan målrettet den specifikke elevgruppe

- Systematisk gennemarbejdede handlingsplaner for skolens udvikling

- Adgang til og forventning om brug af ressourcepersoner

- Tydelig målsætning om krav til kvalitet fra den lokale skoleforvaltning

- Redskaber til etablering af selvevaluering

- Personalet skal involveres i at sætte mål for elevernes læring, monitorering for effekt og evaluering af undervisningen

- Prioritering af indsatser og mål for eleverne - sociale og faglige

- Skolen skal etableres som et læringsmiljø

- Læreren som en del af løsningen og ikke problemet

- Programmer skal iværksættes ud fra elevers behov og evalueres.

\subsection{Grœnsefladen til almenskolen}

Der er to studier, som indgår i grænsefladetemaet. Ved grænseflade forstår vi studier, der ser på, hvordan specialskoler påvirkes af målsætningen om at inkludere flere elever i almenskolen. Disse studier kan bidrage med viden om, hvad der er god kvalitet i specialskolens ageren i forhold til andre skoler. Der er et skotsk og et amerikansk studie. 


\section{Det skotske studie}

Fra 2004 til 2005 foretog University of Glasgow en evaluering af de skotske skoler. En væsentlig del af denne forskning handlede om, hvilken virkning inklusion af elever med særlige behov i almenskolen havde på specialskoler, inklusive en udforskning af specialskolernes ændrede roller og ændrede krav til personalet på specialskolerne. Ændringerne har især påvirket læseplanen, undervisning og læring samt specialskolernes specialisering efter elever med specifikke vanskeligheder (Head E Pirrie, 2007). Det overordnede formål med forskningen var at se, hvordan den nye lovgivning blev modtaget af lokale forvaltninger, og vurdere dens virkninger på alle involverede parter - elever, forældre og lærere såvel som andre professionelle og konsulenter, som støtter elever med særlige behov.

Head $\mathcal{E}$ Pirrie, (2007) gennemførte en surveyundersøgelse af de skotske specialskoler. Spørgeskemaer blev sendt ud til 183 specialskoler i hele Skotland, 119 svarede, hvad der svarer til en deltagelsesprocent på ca. 60 \%. I analysen af data fremhæves fem temaer.

\section{Effekten af inklusion af elever med scrlige behov i almenskolen på elevpopu- lationen i specialskoler.}

Resultater fra surveyen viser ingen tydelig tendens hverken i forhold til en øgning eller nedgang i af antallet af elever på specialskoler. Øget inklusion af elever med særlige behov har ikke haft en signifikant virkning på antallet af elever i specialskoler.

Det fremgår dog af resultaterne, at sammensætningen af de forskellige typer af vanskeligheder hos eleverne på specialskolerne er meget kompleks og udfordrende. 25 skoler har en markant stigning i antallet af elever med autisme spektrum forstyrrelser, og 17 skoler har en stigning i antallet af elever med udfordrende adfærd og/eller psykiske vanskeligheder. Specialskolerne giver i surveyen udtryk for, at den ændrede elevsammensætning har skabt nye udfordringer med det resultat, at det "specielle" ved specialskolerne befinder sig i risikozonen. 
Der er endvidere i den skotske undersøgelse statistisk belæg for (Head $\mathcal{E}$ Pirrie, 2007), at hovedparten af de elever, som p.t. går på specialskoler, er elever i 6. klasse og opefter.

\section{Effekten af inklusion af elever med scrlige behov i almenskolen på personalet på specialskoler}

Resultaterne viser ifølge surveyen, at der er sket en stigning i antallet af lærere på specialskolerne. Statistisk har antallet af lærere på specialskoler altid været genstand for fluktuation i relation til antallet af elever. Denne variation har ikke nødvendigvis noget med øget inkludering at gøre. Til gengæld ses en markant stigning af ikke-uddannede hjælpere (støttepersoner, lærerassistenter m.m.) på specialskolerne. Head \& Pirrie konkluderer, at dette tyder på, at i takt med at specialskolerne ændrer karakter, er der behov for forskellige kompetencer.

Øget samarbejde mellem almen- og specialskolerne

Størsteparten af specialskolerne udtrykker, at samarbejdet mellem almenog specialskolerne er udbygget gennem de senere år, og flere relaterer dette direkte til en øget inkludering. Speciallærerne udtrykker generelt, at de værdsætter dette samarbejde, og at det har haft direkte indflydelse på deres lærerroller.

\section{Organisering af klassen}

Resultaterne peger på, at den øgede inkludering har haft en væsentlig indflydelse på organiseringen af undervisningen på specialskolerne. Tidligere, hvor de enkelte specialskoler var mere specialiserede indenfor bestemte områder, var der en større fleksibilitet omkring, hvordan de organiserede dagen, klasserne og læseplanen. Resultaterne fra surveyen viser, at dette - $\mathrm{i}$ hvert fald på nogle skoler - ikke længere er tilfældet. Det ser ud til, at en "introduktion" til almenlæseplanen har medført, at klasserne på specialskolerne bliver organiseret mere som på almenskolerne.

\section{Undervisningsmetoder}

I forhold til undervisningsmetoder fortæller 21 af skolerne, at der anvendes flere undervisningsmetoder, og yderligere 24 skoler nævner, at de er blevet mere 
fleksible i deres undervisningsmetoder. Specialskolerne i Skotland skal følge retningslinjerne for den skotske læseplan, hvorfor ændringer af undervisningsformer ikke direkte kan relateres til den øgede inklusion.

Resultaterne i studiet peger i retning af, at specialskolernes rolle er ved at ændre sig, og at dette til dels skyldes en øget inkludering af elever med særlige behov i almenskolen. Specialskolerne er mindre "specialiserede", da elevgruppen er blevet mindre homogen, hvorfor personalet i stigende omfang skal tilgodese mange forskellige typer af vanskeligheder. Det medfører, at skolerne skal blive mere "specielle", da lærerne skal udvikle nye færdigheder og metoder til undervisningen af den uhomogene elevgruppe, samtidig med at skolerne får mere tilfælles med almenskolerne i forhold til at arbejde med læseplan og formelle kvalifikationer. Afslutningsvis fremhæves det, at der er stor bekymring for elevgruppen med socio-emotionelle vanskeligheder, som ikke kan leve op til almenskolens krav.

\section{Det amerikanske studie}

Det amerikanske studie er en ph.d.-afhandling af Bott (2009). Det er et eksplorativt, kvalitativt multicase-studie af fire private specialskoler i USA. Formålet med studiet var at undersøge og beskrive "the outreach services", som de private specialskoler udbyder for den lokale, offentlige specialpædagogiske praksis i distriktet, hvor de støtter de lokale specialskoler eller almenskoler med specialklasserækker ved at rådgive dem ud fra deres ekspertise. Grundet den økonomiske krise vælger flere forældre at sende deres børn på de lokale specialskoler eller almenskolerne med specialklasserækker, hvorfor disse p.t. er udfordrede.

Fire private specialskoler med "outreach programs" er inkluderet i projektet. De fire private specialskolers samarbejdsprogram udgør hver sin case.

På de tre af de private specialskoler startede samarbejdet mellem de private specialskoler og den offentlige sektor på baggrund af en henvendelse fra distriktet (svarer til forvaltningen). I alle tre tilfælde var de offentlige skoler ved at udvikle et "indenfor distriktet" klasseværelse til elever med autisme, hvorfor de bad de professionelle fra de private specialskoler om støtte. To af de lokale skoler ønskede at udvikle dette samarbejde yderligere, hvilket resulterede i, at de 
private specialskoler var med til kontinuerligt at udvikle og evaluere de forskellige programmer. På den tredje lokale skole blev der oprettet klasser på skolen, som den private specialskole havde fået ansvaret for.

Den fjerde private specialskole i studiet samarbejder på en anden måde med distriktet. De professionelle på den private specialskole følger elever, der vender tilbage til det lokale specialtilbud. Denne konsultative service fortsætter. Et fælles tema, som opstår på baggrund af analyserne, er behovet for konsultativ bistand i forhold til at yde højt specialiseret evidensbaseret viden, og i forhold til hvilke behov elever med autisme har i undervisningen.

Ledelserne på både de private og offentlige skoler fremhæver, at der er et stort behov for konsultativ bistand, hvis elever med autisme skal sikres en ordentlig undervisningskvalitet. Alle fire skoler refererer til en stigning i antallet af elever, der får diagnosen autisme spektrum forstyrrelser (ASF). Distrikterne forsøger at tilbyde den rigtige undervisning i distriktet og på de lokale skoler, hvorfor lederne giver udtryk for, at der er behov for ekspertbistand i forhold til at evaluere på effekten af indsatserne. Det konkluderes, at efterhånden som antallet af elever med ASF stiger, vil de lokale skoledistrikter skulle tilbyde undervisning til elever med ASF, og de skal stå til ansvar for, at de tilbyder en meget struktureret og videnskabeligt valideret undervisning, som forskningen vurderer, er effektfuld.

\section{Opsummering:}

De to studier giver et interessant billede af, hvordan specialskolerne påvirkes af den øgede inklusion af elever med særlige behov, men også af, hvordan speciallærernes og specialskolernes viden kan videreformidles til almenskolerne. I forhold til kvalitetskriterier kan følgende fremhæves:

- Specialskolerne skal have en tydelig målsætning for deres arbejde - det "specialiserede" ved specialskoler skal bevares

- Øget samarbejde med almenskolerne - speciallærerne får ny viden

- Speciallærerne har fået større indsigt i almenlæseplanen

- Faglige mål for eleverne

- Konsultativ bistand fremmer handlemuligheder 
- Viden om og udgangspunkt i evidensbaserede undervisningsmetoder.

\subsection{Interventioner (faglige og ikke faglige)}

Der er syv studier i materialet, som direkte undersøger virkninger af interventioner eller indsatser i specialskoler. Sådanne studier kan bidrage med viden om virkninger af indsatser og dermed med viden om, hvad der kunne gøre en specialskole god.

Interventionerne dækker indholdsmæssigt et bredt spektrum: et studie om introduktion af et pædagogisk koncept, tre studier om faglige vurderingssystemer, et studie om virkningen af et specialskoletilbud til børn med ASF, to studier om virkning af adfærdsregulerende systemer i specialskolen.

Geografisk fordeler studierne sig således: tre fra USA, to fra Holland, et fra Israel og et fra Belgien.

\section{De tre amerikanske studier}

Golubtchik (2008)har i sin doktorafhandling undersøgt introduktionen af en særlig model, Power of Choice-modellen i én amerikansk specialskole for elever med emotionelle vanskeligheder. Modellen er hentet fra William Glassers Choice Theory. Modellen har implikationer både for konkret praksis og for måden at lede skolen på. Centralt i modellen er hensigten at bryde den onde cirkel med elevadfærd, som straffes, der fører til mere modstandsorienteret elevadfærd, der straffes osv. Heroverfor sætter Glasser en lærer- og lederrolle, der skal facilitere, ikke styre, opfyldelse af grundlæggende behov. I implementeringen af modellen indgik fire forhåndsstrukturerede niveauer, hvor elever kunne anerkendes for både deres adfærdsmæssige og faglige anstrengelser.

Undersøgelsen viser, at det var muligt at ændre skolen i den skitserede retning. Blandt de mere markante resultater var, at mange lærere ændrede syn på deres rolle. Før så de som oftest deres rolle som en plejer for elever med emotionelle vanskeligheder, men inde i processen begyndte de at se deres rolle som primært lærer: Nu var der elever, som gjorde klare fremskridt fagligt og 
adfærdsmæssigt. Dette ikke mindst fordi der nu blev klare mål og niveauer at arbejde med i samværet med eleverne.

Det er en udfordring for specialskoler at måle elevernes faglige progression. Læreres anvendelse af et sådant målesystem, "Washington Alternate Assessment System" (WAAS) portfolio er undersøgt af Johnson \& Arnold (2004). Undersøgelsen sigter mod at belyse målesystemets pålidelighed i faktisk anvendelse på specialskoler. Waas-portfolioen indeholder en elevprofil, en indholdsfortegnelse og scorer på fire områder: kommunikation, læsning, skrivning, matematik. Dette suppleres med en score på elevens generalisering af færdigheder, der scores på tværs i portfolioen.

I undersøgelsen analyseres alle 392 WAAS-portfolioer fra et bestemt skoleår. I resultaterne peges der på tre kilder til lav validitet: En del portfolioer måler ikke på alle fire faglige momenter. En lærers færdighed i at samle en portfolio synes at bidrage til højere scorer hos eleverne. Det giver ikke unik information at inkludere scorer fra de fire faglige områder. Denne undersøgelse bekræfter således specialskolernes udfordringer forbundet med det faglige.

Tobins (2005) doktorafhandling er et multifaktorielt korrelationsstudie, som undersøger en indsats på én specialskole rettet mod 35 elever med emotionelle og adfærdsmæssige vanskeligheder. Indsatsen sigter mod selvregulering og selvtillid ("self efficacy belief"). Baseret på deres aktuelle funktionsniveau blev eleverne placeret på ét af fem træningsniveauer. Niveauerne adskilte sig fra hinanden ved den tilstedeværende grad af ekstern kontrol og omfanget af forventet selvregulering.

Studiet viser, at træningsindsatsen med trindeling og en social-kognitiv tilgang i træningen giver mærkbare forbedringer i elevernes adfærd. Overføring til andre kontekster har hidtil været anset for én af de store vanskeligheder forbundet med denne træning. Her konstateres det imidlertid, at forbedringerne i elevadfærd også er konstaterbare udenfor skolekonteksten.

\section{De to hollandske studier}

En anden undersøgelse af testning på specialskoler er gennemført af Bosma $\mathcal{E}$ Resing (2011) i Holland. Her er fokus på at identificere mulige bidrag fra dyna- 
misk testning i måling af specialskoleelevers behov for undervisning samt at undersøge specialskolelæreres reaktioner på resultater fra dynamiske tests.

Undersøgelsen ser på pædagogiske behov og den individuelle læringsvariation. Designet er en randomiseret kontrolleret undersøgelse, hvor der indgår 36 børn med svage til moderate intellektuelle vanskeligheder.

I eksperimentalgruppen blev anvendt den dynamiske test "Children's conceptual and perceptual analogical modifiability test" (CCPAM). Den er rettet mod analog tænkning. Denne blev fulgt op med elevtilpasset træning i anvendelse af analoge principper.

Undersøgelsens resultater tyder på positive bidrag fra dynamisk testning. Fra lærerside blev resultaterne fra den dynamiske testning vurderet som værdifuld, da lærerne får indsigt $i$, hvordan den enkelte elevs undervisning kan tilrettelægges bedst muligt. Informationen blev vurderet som et supplement til almindelige intelligenstests og blev vurderet som mere positiv, da resultaterne fokuserede på potentiale snarere end på mangler.

En forløbsundersøgelse af Manti E Van Berckelaer-Onnes (2011)ser på 89 elever med autisme spektrum forstyrrelser (ASF) i en hollandsk specialskole. Det undersøges for det første, hvordan elevernes ASF-symptomer udvikler sig over tid, for det andet ses der på elevernes udvikling i faglig henseende, endelig undersøges sammenhængen mellem det førstnævnte og det sidstnævnte. Den læseplan, som eleverne blev mødt med i skolen, var baseret på pædagogiske og psykologiske principper med vægten på facilitering af elevernes kommunikationsfærdigheder, deres adfærdsmæssige færdigheder samt deres sociale og emotionelle færdigheder.

Spørgsmålet om reduktion af ASF-symptomer over tid besvares i studiet tvetydigt, idet elevernes lærere beretter om fald i antallet af symptomer, medens forældrene ikke gør dette. Studiet kunne påvise noget højere faglige resultater over tid for specialskoleeleverne, men stigningstakten lå på et niveau væsentligt under niveauet på almenskoler. Undersøgelsen kunne ikke påvise en sammenhæng mellem reduktion i ASF-symptomer og højere faglige resultater. 


\section{Et israelsk studie}

Bar \& Marcus (1994) har i sit studie undersøgt en formativ evalueringsindsats i naturvidenskabsundervisning af 36 elever på specialskoler i Israel med et "one group pre-post test" design. I undersøgelsen indgik en kombination af testning af elevresultater og observation af undervisning samt interviews af eleverne. Målet med den anvendte og undersøgte evalueringsindsats var ikke at teste eleverne, men snarere at få undersøgt, om det i naturvidenskabsundervisningen kunne lykkes at skabe og anvende undervisningsmaterialer med gode faglige og motivationelle resultater til følge hos eleverne. Dette studie er unikt i sit fokus på fagligt indhold på specialskolen.

Studiets resultater viser, at det faktisk er muligt at anvende mere konventionelle evalueringsredskaber i undervisningen i fysik og biologi. Det personlige interview med eleven gav det sikreste billede af det faglige standpunkt. Forskellige former for skriftlige opgaver og test tilpasset elevernes faglige progression og funktion viste sig dog også til forfatternes overraskelse at kunne bidrage positivt med grundlagsviden for pædagogisk tilrettelæggelse af elevernes faglige progression. Den stærkt individualiserede undervisning, som eleverne kunne få på baggrund af den formative evaluering, var systematisk og trinvis i emner fra biologien og fysikken. I forfatternes konklusion peges der på, at lærerne har behov for at blive vejledt $i$ denne faglige orientering af specialskoleaktiviteterne. Resultaterne fra analyserne af data viser endvidere, at eleverne opnår større fagligt udbytte og bliver mere motiverede for at arbejde med fagene.

\section{Et belgisk studie}

Soenen et al. (2009) har gennemført en undersøgelse i Belgien på en specialskole for elever med emotionelle og adfærdsmæssige vanskeligheder. Studiet har et "one group pre-post test" design. Indsatsen bestod i anvendelse af "Life Space Crisis Intervention" (LSCI), en terapeutisk og verbal strategi brugbar i forhold til børn i krise. LSCI blev integreret $i$ et niveausystem med fem niveauer med hver sit fokus, mål, træningsindhold og belønninger. Systemet blev etableret for at begrænse meget forstyrrende adfærd, for at belønne positiv adfærd og for at opdage ikke-reagerende elever. Skolens personale fik en samlet, grundig oplæring i systemet, og der var coaching undervejs i forløbet. 


\section{KVALITET PÅ SPECIALSKOLER: \\ EN KORTFATTET SYSTEMATISK \\ FORSKNINGSKORTLÆGNING}

Efter indsatsen kunne konstateres en reduktion i elevernes aggressive adfærd, ligesom antallet af registrerede konflikter faldt. Der kunne også konstateres en vis faglig præstationsforbedring. Dette ser forfatterne som et fænomen, der også er forbundet med, at eleverne sjældnere blev væk fra undervisningen.

\section{Opsummering:}

De syv gennemgåede undersøgelser kan tilsammen bidrage med dette:

- At strukturerede, systematiske, trinvise indsatser forbundet med mål og niveauer og træning synes at give gode resultater

- At testning af eleverne, herunder især faglig testning, er forbundet med store udfordringer. Dynamisk testning eller formativ evaluering med et fagligt fokus kan bidrage med forbedret grundlag for undervisningen

- Det faglige moment i skolernes indsats er bemærkelsesværdigt lidt undersøgt. Med en enkelt undtagelse indgår det kun på virkningssiden

- De ansattes primære rolle kan påvirkes fra at være plejer til at blive lærer.

\subsection{Kvalitet set i lcengere tidsforløb}

Tre studier (beskrevet i fire referencer) bidrager med viden om specialskolens kvalitet set i det lidt længere perspektiv, idet den betragtes af eleverne, efter de har forladt skolen. I analysen af kvalitet kan denne vinkel supplere de øvrige studiers betragtning, hvor kvalitet ses under skolegangen på specialskolen eller ved dens afslutning. Undertiden kan der her skelnes mellem "output", det umiddelbare resultat eller udbytte, og "outcome", virkningen på lidt længere sigt. Der er ingen store undersøgelser af dette: To undersøgelser (Sommer et al. og Farrell \& Polat) analyserer alene forholdene på en enkelt dansk og enkelt engelsk skole. Her indgår henholdsvis ni og 26 tidligere elever. Én undersøgelse (Love) undersøger forholdene på specialskolerne i en enkelt stat i USA med 528 tidligere elever og disses forældre. De tre studier er alle gennemført som opfølgende interviewundersøgelser. 


\section{Et amerikansk studie}

Undersøgelsen af Love $\mathcal{E}$ Malian (1997) har fokus på tre omstændigheder i de tidligere elevers liv, efter de har forladt specialskolen: For det første uddannelsesmæssige resultater efter specialskoleopholdet, dernæst hvilke former for støtte de tidligere elever behøver/modtager, samt endelig hvilke indikatorer for livskvalitet der kan karakterisere de tidligere elever. I undersøgelsens design skelnes der mellem elever, som faldt fra inden gennemførelsen af specialskolens program, og elever der gennemførte hele programmet. Dette giver en vis mulighed for at argumentere for forskelle, der er forbundet med specialskolens indsats. Data er repræsentative for specialskoler i Arizona, men de er aggregerede, dvs., at de dækker en lang række meget forskellige elevgrupper og meget forskellige specialskoler. Undersøgelsen er dermed først og fremmest interessant ved sit valg af momenter til undersøgelse.

Det kan konstateres, at en større andel af de elever, der gennemførte det fulde specialskoleforløb, blev studerende i to eller fire års (community) colleges. Den særlige støtte, som specialskolerne kan give i udskolingen af eleverne, fx i form af vejledningsbaseret planlægning af støtte efter skolegangen, herunder jobsøgning, viste sig også at have mest positiv effekt på de elever, der gennemførte specialskoleforløbet. Ligeledes blev markant flere af eleverne, der gennemførte det fulde specialskoleforløb, henvist til en efterfølgende bredere vifte af sociale tilbud (rehabilitering, beskyttet beskæftigelse, psykiatrisk bistand).

Undersøgelsen inddrager også indikatorer som selvhjulpenhed, finansiel uafhængighed, boligforhold og beskæftigelse. En indikator som aktiv "deltagelse i fornøjelser" (fun activities) viste markant mere positive resultater for eleverne, der havde gennemført specialskolen. Også forholdet til venner syntes at blive påvirket positivt af specialskolens indsats. Forekomsten af misbrugsproblemer og kriminalitet udviste ingen signifikante sammenhænge med gennemførelse.

\section{Et dansk studie}

En dansk undersøgelse af Sommer et al. (2006) har fokus på én bestemt specialskoles indsats og på elevernes opfattelse af, hvad de har lært på skolen, som de senere har kunnet bruge i deres tilværelse. Skolen er indrettet for elever med 
ADHD og/eller ASF. Undersøgelsens resultater er rapporteret som ni små fortællinger, hvor konkrete tidligere elevers meninger om specialskolen kommer til udtryk. Disse individuelle historier følges af rapportens forfattere op af en tværgående opsamling.

De ni historier er meget forskellige. De viser, at den skole, disse elever har gået på, i en vis forstand har været ni forskellige skoler - og ikke én. Derved kan disse data indirekte give et bud på kvaliteten af skolens individualiseringsindsats.

Mange af eleverne kommer ind på forholdet mellem elev og lærer. Der peges på betydningen af den positive anerkendende måde at blive mødt på, men også på det problematiske i fraværet af det anerkendende, når asymmetrien dominerer, fx ved fysisk magtanvendelse.

Selvindsigt og selvværd indgår også i flere af de tidligere elevers udsagn. Dette at få noget mere viden om den sygdom, man bærer, blev her udtrykt som et ønske til skolen.

I tilbageblikket på undervisningen indgik også det positive tryghedsmoment, som specialskolens lille klassestørrelse kunne give anledning til, set i forhold til de 4-5 gange større almenskoleklasser.

Eleverne kommer også, dog i mindre grad, ind på det faglige i undervisningen. Nogle peger på det gode $i$, at undervisningen bliver målrettet mod eksamen, gerne på anderledes måder med brug af praktiske materialer.

Fritidsaktiviteterne for de tidligere elever omtales som rundet af de samme interesser, eleverne havde, da de gik i specialskolen. Alle ni elever arbejder eller er i gang med en uddannelse - de udtrykker selv, at de lever "et godt nok liv".

\section{Et engelsk studie}

En engelsk specialskole for elever med emotionelle eller adfærdsmæssige vanskeligheder (EBD) indgår i en undersøgelse af Polat og Farrell (2002). Undersøgelsen sigter mod at nå ind til tidligere elevers mening om kvaliteten af den uddannelse og omsorg, de fik, medens de gik på skolen. Undersøgelsen er baseret på 26 interviews. 
Elevernes tilbageblik på kvaliteten af relationen til lærerne og andre elever viser, at langt de fleste havde et meget positivt syn. Flertallet beklagede sig dog over at måtte sige farvel til venner og lærere på den skole, de gik på, inden de kom på specialskolen, og at det i starten var vanskeligt at få nye venner.

Kvaliteten af uddannelsen på specialskolen udtrykte næsten alle stor tilfredshed med. Kun fire af de tidligere elever udtrykte stor utilfredshed med uddannelsen på skolen. Forhold som de små klasser, den større overskuelighed, lærere med tid til den enkelte elev, inddragelse af fritidsaktiviteter som en del af skoletilbuddet pegede eleverne på som positive.

Alle tidligere elever gav udtryk for stor tilfredshed med den omsorg, de fik på specialskolen. Udtryk som at få og modtage tillid, at være respekteret, at have nogen, der har tiden og lysten til at være til stede, og som også fortæller direkte, hvad der måtte være forkert.

Når eleverne skal vurdere skolens påvirkning af deres emotionelle og adfærdsmæssige vanskeligheder, peger mange på forøget selvværd og bedre selvkontrol.

\section{Opsummering:}

De tre gennemgåede undersøgelser om skolevirkninger på det lidt længere sigt udgør ikke en sikker evidensbase med viden om "output" og "outcome" forbundet med specialskoler. Så i denne forstand kan kvalitetsspørgsmålet ikke belyses sikkert. Studierne kan derimod bidrage med:

- Mulighed for at lade specialskoleeleverne selv indgå i bestemmelsen af god kvalitet

- Mulighed for at betragte specialskolens kvalitet også under en lidt længere tidsdimension

- Mulighed for at lade en bredere vifte af senere indikatorer indgå i kvalitetsbestemmelsen af specialskolen: livskvalitet, beskæftigelse, senere uddannelse etc.

- Det må konstateres, at der her er et felt, der er meget lidt undersøgt. 


\section{Afrunding}

Der er blevet arbejdet med disse reviewspørgsmål: Hvilke forhold i en specialskole har positive effekter på eleverne? Hvad gør en specialskole god, eller hvad er god kvalitet på en specialskole?

\subsection{Kvalitet}

Som en indledning til at besvare dette ses der først lidt nærmere på kvalitetsbegrebet.

Den oprindelige betydning af ordet 'kvalitet' kommer fra latin, qualitas, der betyder beskaffenhed. Oprindelig ses kvalitet som egenskaber ved et fænomen. Et fænomen er, hvad det er i kraft af sine kvaliteter. Således betragtet kan et fænomen altså beskrives ved sine kvaliteter. Kvalitet er her kort fortalt et empirisk fænomen.

Når kvalitetsbegrebet tages i anvendelse i uddannelsessammenhæng, indgår der også forestillinger, som har karakter af forventninger, ønsker eller værdier knyttet til fænomenet. Nu er det ikke bare fænomenet i sig selv, der anskues, men fænomenet som anskues i forhold til forventninger, ønsker eller værdier. Dvs., et fænomen har kvalitet, når det lever op til visse forventninger, ønsker eller værdier. Således betragtet har eller får et fænomen mere eller mindre kvalitet. Kvalitet er her kort fortalt et spørgsmål om mål.

Uddannelseskvalitet er således et forhold, der kan undersøges i et samspil mellem det, der er, og det, der burde være. I denne forstand forudsætter meningsfuld undersøgelse af kvalitet faktisk først en bestemmelse af, hvad der er kvalitet.

I uddannelse kan kvalitet i den dobbelte betydning, som her er anført, forbindes med både proces og output. På output-siden kan det være spørgsmål om fagligt udbytte, socialt udbytte, personlighedsmæssigt udbytte etc. På processiden kan der både peges på kvalitet i sig selv af særlige former for pædagogisk indsats, eller der kan peges på, at processen har kvalitet, hvis den bidrager til et vist ønsket output.

Anvendelse af kvalitetsbegrebet i uddannelsessammenhæng forudsætter dermed på én gang klarhed i formulering af mål og empirisk konstatering af, 
hvordan det så forholder sig med det fænomen, der formuleres mål for. I forbindelse med vores analyse af anvendelse af kvalitetsbegrebet i specialskolesammenhæng har det vist sig, at begge forhold yderst sjældent indgår i forskningen på én gang.

\subsection{Karakteristika ved den specialpœdagogiske forskning?}

Med udgangspunkt i reviewspørgsmålet søgte vi relevante studier i en central mængde af databaser (se s. 2). Disse søgninger resulterede i 709 referencer. Vi har mundtligt diskuteret referencerne, men vi har ikke i rapporten gennemført indgående videnskabelige diskussioner af enkeltstående studier og kun i beskedent omfang af bestemte forskningsområder. Ud af de 709 fundne referencer resterer 28 indholdsmæssigt relevante.

En del af de udelukkede referencer har karakter af "diskussions- og holdningsstudier". Disse studier kan godt være værdifulde, og de kan ud over den formidlende funktion tjene som indledning til grundlæggende forskning. Det interessante er, at studierne om specialskolernes kvalitet ikke er præget af den empiriske forskningstradition, hvor der formuleres en problemstilling, som derefter belyses med et empirisk materiale.

I flere af de udelukkede referencer er det fx skolelederen af en specialskole, der vurderer kvaliteten af egen specialskole. Skolelederens binding til sin skole kan medføre en stærk loyalitet med skolen og et fravær af reflekteret, kritisk vurdering af skolen. Ud fra de gennemgåede referencer er der noget, der tyder på, at forskere indenfor det specialpædagogiske felt føler sig mere som støtter til skolen end som dens kritikere og analytikere.

Det er også en kilde til undren, at der slet ikke er fundet undersøgelser af specialskoler, der direkte inddrager skoleeffektivitetsforskningens foretrukne forskningsdesign, hvor flere forhold i skolen i et multifaktorielt design ses i forhold til de virkninger, der skabes på eleverne, medens der kontrolleres for elevernes sociale baggrund og faglige dygtighed. I Dansk Clearinghouse for Uddannelsesforskning er der gennemført et systematisk review om denne forskning forbundet med almenskoler, der i meget høj grad på én gang belyser begge sider af kvalitetsbegrebet (Nordenbo et al., 2010). 


\subsection{Effektundersøgelser}

Syv studier undersøger direkte virkninger af indsatser på specialskolernes elever. Sådanne studier kan bidrage med viden om, hvad der kunne gøre en specialskole god. Disse undersøgelser belyser på én gang begge sider af kvalitetsbegrebet. Studierne dækker indholdsmæssigt et bredt spektrum: et studie om introduktion af et pædagogisk koncept, tre studier om faglige vurderingssystemer, et studie om virkningen af et specialskoletilbud på børn med ASF, to studier om virkning af adfærdsregulerende systemer i specialskolen.

På tværs af disse studier kan der peges på, at strukturerede, systematiske, trinvise indsatser forbundet med mål, niveauer og træning synes at give gode faglige og sociale resultater hos eleverne.

Det har videre vist sig, at testning af eleverne, i særdeleshed faglig testning, er forbundet med store udfordringer. Dynamisk testning eller formativ evaluering med et fagligt fokus kan bidrage med forbedret grundlag for undervisningen og dermed et forbedret elevudbytte.

Kun et enkelt af disse studier undersøger en indsats rettet direkte mod elevernes faglige udvikling.

I forbindelse med flere af disse undersøgelser blev iagttaget en forskydning af den specialskoleansattes oplevede rolle fra mindre plejer til mere lærer.

\subsection{Evaluering - en forudscetning for kvalitet på specialskoler?}

Resultaterne peger i retning af, at der mangler en evalueringskultur på specialskolerne. Det konstateres, at elevernes udbytte af et specialskoleophold sjældent evalueres i forhold til faglig og anden udvikling. Evaluering er ikke nødvendigvis en del af praksis på specialskoler. Resultaterne her påpeger nødvendigheden af at etablere en evalueringskultur på specialskolerne, hvis kvaliteten på skolerne skal optimeres.

En af KVIS-programmets kvalitetsindikatorer er Tema 1: Individuel tilrettelæggelse og gennemførelse af undervisningen. Af de speciallærere, som deltager i undersøgelsen, svarer $63 \%$, at de forsøger dette i praksis. Der er altså specialskoler, hvor en evaluering af elevens faglige og sociale udvikling (i hvil- 
ken udstrækning de respektive områder vægtes, vides ikke) forekommer, da disse nødvendigvis må være en del af en individuel undervisningsplanlægning. Ses der på resultaterne af studier, hvor OFSTED-rapporterne er inddraget, er der en del, der tyder på, at specialskolerne kan have stort udbytte af en egentlig kvalitetsvurdering. Ca. $8 \%$ af de engelske specialskoler er sat under special measures, (hvor blot $2 \%$ af almenskolerne er sat under tilsvarende opsyn), hvilket betyder, at skolernes virke ikke lever op til de enkelte elevers uddannelsespotentiale.

Det fremgår i flere studier, at lærere på specialskoler ikke har tradition for at evaluere egen undervisning i forhold til den anvendte pædagogik og kognitive resultater. Der beskrives endvidere en positiv effekt af, at lærere bliver direkte involverede $\mathrm{i}$ at udarbejde evalueringsprogrammer.

\subsection{Faglig og social udvikling - er det tegn på god kvalitet på en specialskole?}

I de inkluderede studier er der et enkelt studie, som beskriver faglige målsætninger for eleverne på specialskoler. Det beskrives endvidere, at data om elevernes faglige udvikling ikke udveksles mellem specialskolerne og almenskolerne, der er med andre ord ikke tradition for, at viden om eleverne videregives. Dette er især problematisk, da andre studier viser, at netop samarbejdet mellem almenlærere og speciallærere har en positiv effekt på speciallærernes faglige målsætninger i forhold til deres egne elever. De opnår blandt andet en større viden om planlægning af undervisning og læring.

Viden fra speciallærerne om etablering af undervisningsmiljøer for inkluderede elever i almenskolen er også et centralt resultat. Denne vidensdeling mellem special- og almenlærerne kan fungere som en konsultativ bistand til de to respektive skolesystemer.

Det er endvidere interessant at se på, hvilke områder der vægtes, når der skal foretages baseline-vurderinger for elever på henholdsvis special- og almenskoler. Specialskolerne evaluerer primært de sociale og personlige færdigheder hos eleverne. På almenskolerne er det mere kognitive færdigheder, der bliver evalueret på. 


\subsection{Forcldre- og elevsamarbejde - har det betydning i forhold til kvalitet på specialskoler?}

De få studier, som inddrager forældre og forældresamarbejde i analysen, tyder på, at forældresamarbejdet kan have betydning for kvaliteten af undervisningen. Der kan her peges på det positive syn på skolen og dens virksomhed, som forældrene ofte synes at bære med ind i samarbejdet med specialskolen. Når den viden, som forældre har om deres barn, inddrages i samarbejdet med skolen, vil skolens muligheder for at tilgodese barnets behov kunne øges markant. Forældre-specialskole-samarbejdet indgår da også i de kvalitetsindikatorsystemer for specialskoler, der er forbundet med forskning, som er behandlet i denne analyse.

Samarbejdet med eleverne er ikke direkte genstand for undersøgelse. Undersøgelse af dette ville som minimum forudsætte, at også eleverne selv direkte blev informanter om samarbejdet i undersøgelsen. I de undersøgelser, der er gennemgået her, er dette kun tilfældet i dem, der betragter skolens virkning på det lidt længere sigt, efter at specialskolen er forladt. Disse studier viser, at det er muligt, at specialskoleeleverne selv indgår i vurdering af kvalitet.

Betragtes samvirket mellem lærere og elever, er dette belyst i flere studier. Tilsammen peger de på, at når samvirket er præget af systematiske, trinvise indsatser forbundet med klare mål, niveauer og dertil-hørende træning, forbedres kvaliteten af elevernes læreproces.

\subsection{Evaluering og målsœtninger for hele specialskolen er kvalitets- indikatorer for specialskoler}

Det kan afslutningsvis konkluderes, at evaluering af og målsætninger for hele specialskolen vil medføre et kvalitetsløft for specialskolerne. Det er bemærkelsesværdigt, at så få studier har kunnet indgå i dette kortfattede review, da kvaliteten af studier om kvalitet på specialskoler er af normativ karakter.

En evaluering af de enkelte skolers praksis vil åbne mulighed for, at skolerne kan arbejde med effektive handlingsplaner og målsætninger for deres og elevernes kontinuerlige udvikling. Dette medfører endvidere, at der må udarbejdes undervisnings- og læringsmål for denne elevgruppe. 
Såvel almenskolerne som specialskolerne har behov for nogle klare og tydelige mål for deres skolers kvalitet og en tydelig og klar målsætning fra den lokale forvaltning om, hvilke specifikke kvalitetsmål specialskolerne bygger på. 


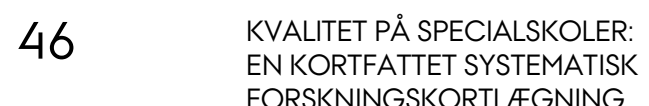

FORSKNINGSKORTLÆGNING

\section{De inkluderede studier}

Baltzer, K. (2003). Vidtgående Specialundervisning - Den ændrede opgavefordeling og KVIS-programmet: Danmarks Evalueringsinstitut.

Bar, V., \& Marcus, Y. (1994). Formative evaluation and instruction of the natural science. Issues in Special Education \& Rehabilitation, 9(2), 71-86.

Beyer, F. (2009). Individualisierung als Leitbild. Eine Empirische Untersuchung zur spezifischen Qualität der Blinden und Sehbehindertenpädagogik. Berlin: Probusiness Verlag.

Bosma, T., \& Resing, W. C. M. (2011). Need for instruction: dynamic testing in special education. European Journal of Special Needs Education, 27(1), 1-19.

Boström, L. (2008). Begåvningsstöd och begåvningshjälpmedel : en beskrivning från särskolan. Stockholm: Specialpedagogiska skolmyndigheten.

Bott, C. L. (2009). Collaborative consultation: A multicase study of the partnership between private and public special education programs for students with autism. New Brunswick, NJ: Rutgers State University.

Danmarks Evalueringsinstitut (2003) - S. 10

Davies, J. D., Lee, J., Postlethwaite, K., Tarr, J., Yee, W. C., \& Thomas, G. (1999). After Inspection in Special Schools: Action Planning and Making Progress. British Journal of Special Education, 26(3), 130-135.

Dobbins, M., \& Abbott, L. (2010). Developing partnership with parents in special schools: Parental perspectives from Northern Ireland. Journal of Research in Special Educational Needs, 10(1), 23-30.

Farrell, P., \& Polat, F. (2003). The long-term impact of residential provision for pupils with emotional and behavioural difficulties. European Journal of Special Needs Education, 18(3), 277-292.

Garbe, G. (2000). Organisation und Qualität sonderpädagogischer Grundversorgung. Sonderschule Wiesmoor - Erfahrungsbericht zum Pilotprojekt. Beispiele. Niedersachsen Schule machen, 18(2), 18-23. 
Golubtchik, H. (2008).The transformation of the last chance school, a school for severely emotionally disturbed students. Prescott, Arizona: Northcentral University.

Head, G., \& Pirrie, A. (2007). The place of special schools in a policy climate of inclusion. Journal of Research in Special Educational Needs, 7(2), 90-96.

Johnson, E., \& Arnold, N. (2004). Validating an Alternate Assessment. Remedial and Special Education, 25(5), 266-275.

Kelly, Á., Carey, S., McCarthy, S., \& Coyle, C. (2007). Challenging behaviour: Principals' experience of stress and perception of the effects of challenging behaviour on staff in special schools in Ireland. European Journal of Special Needs Education, 22(2), 161-181.

Lehr, C. A., Tan, C. S., \& Ysseldyke, J. (2009). Alternative Schools. Remedial and Special Education, 30(1), 19-32.

Lewis, A., Lindsay, G., \& Phillips, E. (2003). Assessment in special schools: national early assessment procedures and pupils attending special schools in England. European Journal of Special Needs Education, 18(2), 141-153.

Love, L. L., \& Malian, I. M. (1997). What happens to students leaving secondary special education services in Arizona? Implications for educational program improvement and transition services. Remedial and Special Education, 18(5), 261-. Male, D. B. (1999). Special school inspection and its effects on teachers' stress and health, workload and job-related feelings: a case study. European Journal of Special Needs Education, 14(3), 254-268.

Manti, E., Scholte, E. M., \& Van Berckelaer-Onnes, I. A. (2011). Development of children with autism spectrum disorders in special needs education schools in the Netherlands: a three-year follow-up study. European Journal of Special Needs Education, 26(4), 411-427.

Neil, P., McEwen, A., Carlisle, K., \& Knipe, D. (2001). The Self-Evaluating School - A Case Study of a Special School. British Journal of Special Education, 28(4), 174-181.

Pickering, D., \& Wilton, K. (1996). The New Zealand Special School Project: An Evaluation of a Special School System (pp. 12-12). 


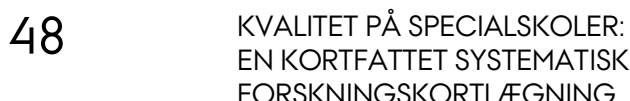

FORSKNINGSKORTLÆGNING

Polat, F., \& Farrell, P. (2002). What was it like for you? Former pupils' reflections on their placement at a residential school for pupils with emotional and behavioural difficulties. Emotional \& Behavioural Difficulties, 7(2), 97-108.

Soenen, B., Goethals, I., Spriet, E., D'Oosterlinck, F., \& Broekaert, E. (2009). Effects of the combination of life space crisis interventions and a level system at the therapeutic treatment centre 'Heynsdaele'-A special school and home for youth with behavioural and emotional problems. Therapeutic Communities, 30(2), 200-216.

Sommer, T., Sørensen, B., \& Hovmand-Olsen, L. (2006). What did you learn in school today? What did your teacher say?: effektundersøgelse, hvilken betydning har det at gå på en specialskole? Viby J.: Langagerskolen.

Thomas, G., Yee, W. C., \& Lee, J. (2000). "Failing" Special Schools - Action Planning and Recovery from Special Measures Assessments. Research Papers in Education: Policy and Practice, 15(1), 3-24.

Thurston, C. J. (1998). A systems approach to the evaluation of a social and emotional development program for emotionally disturbed elementary school students in a private special education facility. New Brunswick, NJ: Rutgers State University.

Tobin, S. E. (2005). Assessing of self-regulation training system and its transfer to out-of-school contexts for students with emotional and behavioral difficulties. AAI3169991. New York: City University.

Östlund, D. (2008). Särskolans modersmålsundervisning. Kristianstad: Högskolan Kristianstad. 


\section{Anden anvendt litteratur}

Pirrie, A., Head, G \& Brna, P. (2006). Mainstreaming pupils with special educational needs: An evaluation. Edinburgh: Scottish Executive.

Nordenbo, S.E., Holm, A., Elstad, E., Scheerens, J., Søgaard Larsen, M., Uljens, M., Fibæk Laursen, P., \& Hauge, T.E. (2010). Input, Process, and Learning in primary and lower secondary schools. A systematic review carried out for The Nordic Indicator Workgroup (DNI). Copenhagen: Danish Clearinghouse for Educational Research, DPU, Aarhus University 




